\title{
AN OPTIMAL PORTFOLIO COMPARISON OF SYARIAH STOCKS BEFORE AND AFTER THE WEAKENING OF THE 2015 INDONESIAN ECONOMY
}

\author{
Ahmad Ridho Darmawan ${ }^{1 *}$ \\ ${ }^{1}$ Universitas Islam Negeri Walisongo, Semarang, Indonesia
}

\begin{abstract}
This paper contains the results of a comparative study of Islamic stock portfolios between the years of 2014-2016. In 2015, Indonesia's economic growth experienced the lowest weakening in the past 6 years. The Jakarta Islamic Index (JII) on 2014 experienced an uptrend, in 2015 it rebounded to a downtrend, and in 2016 an uptrend is experienced again. The purpose of this study was to compare the performance of Islamic stock portfolios before, during and after the weakening of the Indonesian economy and to find the impact of the optimal portfolio strategies in conditions of fluctuating economic growth performance. The population are all the Islamic stocks that are listed on JII in every period during the years of 2013 - 2016. The sample used the Purposive Sampling method, the portfolio performance assessment used the Treynor index and analyzed the data using the Paired-sample T-Test. The results of the study are that (H1) was rejected with a significance value of 0.699>0.05, (H2) was rejected with a significance value of $0.910>0.05$ and $(\mathrm{H} 3)$ was rejected with a significance value of $0.797<0.05$. In conclusion, all the hypotheses $(\mathrm{H} 1, \mathrm{H} 2$, H3) are rejected and $\mathrm{HO}$ is accepted. Based on these results, the use of the optimal portfolio method in investment is able to minimize the risks, although it doesn't eliminate the risk.
\end{abstract}

Keywords: Jakarta Islamic Index, Stock Portofolio, Stock Return, Stock Risk

\section{INTRODUCTION}

In the year 2015 the growth of Indonesia's Gross Domestic Product (GDP) is as large as $4.87 \%$ which became the lowest in the last 6 years. This condition is the first GDP growth under 5\% since the year 2010 .

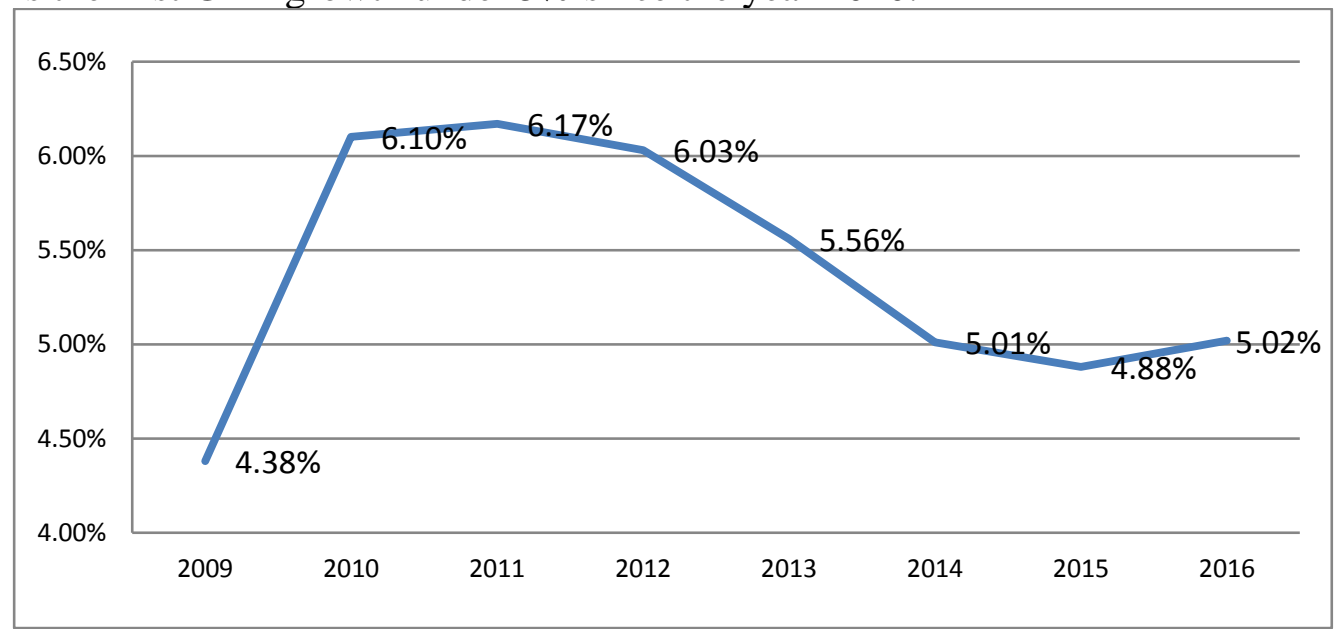

Figure 1 Indonesia GDP Growth 2009-2016 (Percent)

Source: Secondary data from the Central Body of Statistics which was processed by the Data Center and Information System, Ministry of Trade

* Corresponding author. Email address: ahmadrdy17@gmail.com 


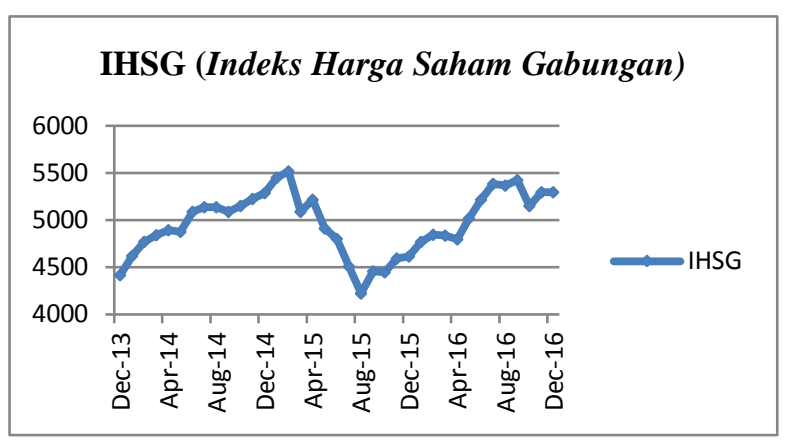

Figure 2 Monthly Growth of Combined Stock Price Index

December 2013-December 2016 Source : IHSG secondary data

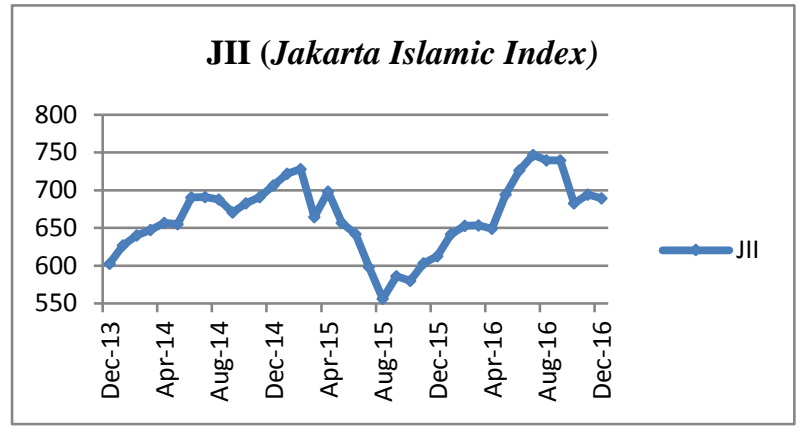

Figure 3 Monthly Growth of Jakarta Islamic Index (JII) December 2013-December 2016 Source: JII Secondary data

In line with the GDP growth, the Combined Stock Price Index and Jakarta Islamic Index in the monthly growth of the December 2013-December 2016 period showed the same performance.

Based on the stock index data, the Combined Stock Price Index and the Jakarta Islamic Index showed the macroeconomic condition that provides performance influence in general. Yet it does not mean the JII performance development illustrates the performance of each stock in the listing at that period as the same with the index performance. For example, the return that is shown by the stock of AALI, ADRO and AKRA which are always on the listing for the years of 2014-2016.

Table 1 Return Stock of AALI, ADRO, AKRA in the Closing of 2014-2016

\begin{tabular}{llll}
\multicolumn{1}{c}{ Stock Code } & \multicolumn{1}{c}{ Year. 2014 } & \multicolumn{1}{c}{ Year. 2015 } & \multicolumn{1}{c}{ Year. 2016 } \\
\hline AALI & $-3 \%$ & $-35 \%$ & $+11 \%$ \\
ADRO & $-4 \%$ & $-50,4 \%$ & $+229 \%$ \\
AKRA & $-5,8 \%$ & $+74,15 \%$ & $-16,4 \%$ \\
\hline
\end{tabular}

Source : Secondary Data of AALI, ADRO, AKRA Return Stocks 2013-2016 which are already processed

Table 1 shows the price fluctuation of some stock which are in the JII list, yet there is an incompatibility with the JII value trend in some stock. In other words the return of each stock does does not always follow the performance trend and the formed stock index, and it shows a development that is not positive or negative. The conclusion is that although investment in stocks can be appropriate with the syariah principle, Stock investment is still an economic business investment which has risks and no guarantee of return inside it.

In the investment process, determining strategy, forming and managing a portfolio is considered adequately important, A portfolio is defined as a series of combinations of several assets which are invested by investors. The forming of a portfolio is meant so that investors implement diversification in asset selections for optimizing the profit expectation and minimize risk chances with a logical reason and analysis, so the speculation practice is avoided. The modern portfolio approach was first introduced by Harry M. Markowitz. The portfolio theory that was introduced by Markowitz assumed that investors make their investment decisions based on the expected return and portfolio risk. 
The optimal portfolio other than inputting assets in stock form with the highest profit and lowest risk, also considers the proportion and allocation of funds in the portfolio forming assets. The most important matter in the forming of the syariah stock optimal portfolio based on the JII is the meaning that listed stocks in JII which are the portfolio forming objects are 30 of the most liquidable syariah stocks and continue to fluctuate and recorded in the Syariah Effect List. Although each stock has different risks and returns, the economic phenomenon in Indonesia very much influences the performance or the JII index value. Especially in 2015 where the Indonesian and global GDP conditions experienced the lowest growth in the last 6 years. Although not all the stock are impacted by JII performance. So this shows the urgency about the importance if portfolio performance assessment of syariah stock in the periods before, in and after the Indonesian economic weakening in 2015.

\section{LITERATURE REVIEW Investment}

In the Al-Qur'an Surah Al-Hasyr verse 18 Allah stated:

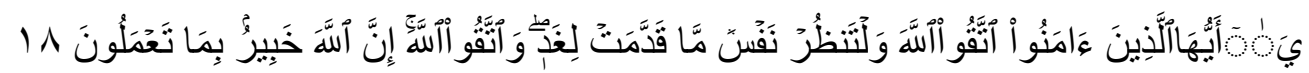

Meaning: $O$ who believe, follow Allah and each self should be attentive to what they do for tommorrow (the afterlife); and follow Allah, truly Allah is the All Knowing of what you do

In that verse, Allah orders all believers to oblige to follow Allah and the attitude of the followers is that every believer should be attentive to what they do for tommorrow. The emphasis of this verse, is that for every believer, one of the forms of following Allah is by preparing the life for tommorrow (investment). So indirectly, a form of belief and following for every muslim is investing with the intention because of Allah, to strengthen their belief.

Investment itself is based on the word invest meaning to plant. Donald $\mathrm{E}$. Fischer and Ronald J. Jordan in their book Security Analysis and Portfolio Management, defined that an investment is a commitment of funds made in the expectation of some positive rate of return". Jack Clark Francis, in his book Investment : Analysis and Management, defined that: "an investment is a commitment of money that is expected to generate of additional money" Investment is a process of managing assets which are able to provide results in the future. So it can be concluded, investment is a commitment in allocating an asset in the form of money or other resources with the expectation an consideration to obtain a positive result in the future. The investment activity if observed from the object is divided into two objects, which are investment in real assets (assets in physical form such as land, buildings and the like) and investment in monetary assets (assets in the form of securities (effects) such as syariah bonds, syariah stock and other securities),

\section{Syariah Stock}

Stock is a proof of the company assets that issue the stock. While in the syariah principle, the addition of capital is implemented in companies that do not follow the syariah principle such as gambling, usury, producing forbidden goods. Generally according to the bill right there are two types of stock, common stock and preferred stock. Common stock are the most plentiful 
securities and are spreaded in the trade. While what is named as preferred stock is because the holder has special rights above usual stockholders, in certain matters that are agreed in the stock emission. This privilege is different between one emmitance and other emmitances which are the agreement results between investors or stockholders with emmitance.

\section{Return Stock}

Basically there are 2 results (returns) in stock investment among others:

\section{a. Divident}

A divident is profit sharing that companies provide to investors and is from the profit that the company produces.

b. Capital Gain

Capital Gain is the difference between the selling price and buying price of stock and cash divident which is obtained from emmitance because companies obtain profit, this gain is formed with the presence of stock trade activities in the secondary market.l

\section{Stock Risk}

Risk is also defined as a probability of the occurrence of loss which investors will experience or an uncertainity of the return which will be obtained in the future. So, risk is defined as a chance that an unwanted occasion will occur. In the stock investment context in the capital market, risk can be divided into two types which are:

\section{a. Systematic risk}

A systematic risk as a risk which cannot be eliminated by diversification, because the fluctuation of this risk is influenced by macroeconomic factors which are able to be influenced by macroeconomic factors that can influence the market as a whole. Such as the change of interest levels, foreign exchange rates, government policies and others.(

b. Unsystematic risk

An unsystematic risk is a risk that can be eliminated by diversification, because this risk is only present in one company or certain industries such as the capital structure factor, Asset structure, liquidity levels, profit levels and others.

\section{Single Index Model Portfolio}

The single index model portfolio is a simplification of the index model developed by Markowitz. Developed by William F. Sharpe in 1963, it explains the relation between returns from each asset in the market index return. The single index model divides the return from an effect into two primary components which are:

1. The ereturn component related with company uniqueness: symbolized with $\alpha_{\mathrm{i}}$;

2. The return component related with the market; symbolized with $\beta \mathrm{i} . \mathrm{R}_{\mathrm{m}}$.

Primarily, the steps implemented for forming a portfolio are

a. Counting the stock return level $\left(\mathrm{R}_{\mathrm{i}}\right)$ and expected return $\left(\mathrm{E}\left(\mathrm{R}_{\mathrm{i}}\right)\right)$; 
b. Counting the market return index $\left(\mathrm{R}_{\mathrm{m}}\right)$, alpha $\left(\alpha_{\mathrm{i}}\right)$ and beta $\left(\beta_{\mathrm{i}}\right)$;

c. Counting the deviation standard and residual variant (unsystematic risk);

d. Counting the excess return to beta (ERB)

e. Counting the cut-offpoint $\left(\mathrm{C}^{*}\right)$

f. Counting the portion of each stock

g. Counting the expected return portfolio

h. Counting the portfolio risk by determining the variant size of the portfolio.

The forming of the optimal portfolio using the single index model is determined from the excess return to beta (ERB) from a positive effect then compared with the cut-offpoint value $\left(\mathrm{C}^{*}\right)$ the effect that has an ERB is larger or the same with $\mathrm{C}^{*}$ so it will be in the optimal portfolio candidate with the single index method.

\section{Risk Adjusted Performance}

This concept is based on the Capital Market Theory which is a portfolio performance measurment concept pioneered by William Sharpe, Treynor, and Michael Jensen with the term of composite (risk-adjusted) meeasure of portofolio performance.

\section{Treynor Index}

The Treynor Index is a measure of portfolio performance developed by Jack Treynor (1965) and this index is often also called the reward to volatility ratio (RVOR). The portfolio performance in the Treynor Index is observed by connecting the return portfolio level with the risk size from the portfolio. The assumption is that the portfolio is already diversified well so the risk considered relevant is the systematic risk (market risk) measured with beta.

$$
\text { Treynor }(T p)=\frac{R p-R f}{\beta p}
$$

\section{Previous Research}

Some previous research which support and even almost similar, from the methodical and the research object, for becoming reference materials as sources of reference and a comparison in this research. Some of the previous research are among others:

1. Agustin Sulistyorini (2009) in her thesis titled "Analisis Kinerja Portofolio Saham dengan Metode Sharpe, Treynor, dan Jensen (Saham LQ45 di Bursa Efek Indonesia Tahun 2003-2007)", stated that there is no significant difference between testing with the sharpe, treynor and jensen methods. Where $\mathrm{H} 0$ in this research is accepted, which is in the absence of a difference of LQ45 stock portfolio which was evaluated by usingthe Sharpe, Treynor and Jensen methods. In this research the writer implemented research in the form of comparing evaluation results from the three methods by a difference testing method using the one way of variance by rank with Kruskal-Wallish. The result formed a value of $=1.906$ with a probability of 0.386 . So that result is known from the test probability which is $\geq 0.05$ and a count of $<$ table 5.99 .

2. Ratna Utami and Maha Putra Kusuma in their research titled "Analisis Kinerja Saham Syariah dan Pengaruhnya Terhadap Respon Pasar Pada 
Perusahaan yang Tercatat di $J I I$ " showed counting results of the Jakarta Islamic Index market parameter in the December 2008 - November 2010 period, the JII index provided a market return rate $(\mathrm{Rm})$ positively valued at $0.108 \%$ and larger than the return rate of the risk free investment as large as $0.625 \%$.

3. Imam Edi Subekhi (2012) in his thesis "Analisis Perbandingan Kinerja Portofolio Saham Syariah Sebelum dan Sesudah Listing di Jakarta Islamic Index (Studi pada saham-saham di JII periode 5 Desember 2008-8 Juni 2011)" studied about the optimal portfolio performance of syariah stock formed based on a time period, which is before, in, and after the JII listing in the period of 2008-2011. With the Treynor Index assessment method, the result of the assessment of the three portfolios is compared with by implementing the two direction difference test (paired sample T test). The result showed that the comparison between portfolios when listing with 3 months before listing provided a $t_{\text {count }}$ as large as 76.805 with a 0.000 probability. So $\mathrm{H} 0$ is rejected and $\mathrm{H} 2$ is accepted, which there is a significant difference between in the listing with 3 months after the JII listing. And lastly the portfolio performance comparison of 3 months before listing with the portfolio of 3 months after listing of JII, it provides a value as large as 3.560 with a probability of 0.003 . So $\mathrm{H} 0$ is rejected and $\mathrm{H} 3$ is accepted. This research tested 3 portfolios based on 3 different time periods as a cause of an evaluation event and listing in JII.

\section{Framework}

The primary problem of this research is observing the influence of the Indonesian economic condition in 2015 to the significance of a difference of an optimal portfolio of syariah stock formed from syariah stock issued in JII in the years before economic growth weakening (2014), in the economic growth weakening (2015) and after the economic growth weakening (2016). By using the portfolio performance assessment of risk adjusted performance (Treynor Index). The optimal portfolio is formed from shares listed in JII and corresponding to the sample criteria before tne years of the Indonesian economic growth weakening in 2015 is named as the 2014 Portfolio. While the one that is formed in the year of the Indonesian economic growth weakening in 2015 is named as the 2015 Portfolio. And the one that is formed after the year of the Indonesian economic growth weakening is named as the 2016 portfolio. Based on the assumption and explanation above, the following framework is formed. 


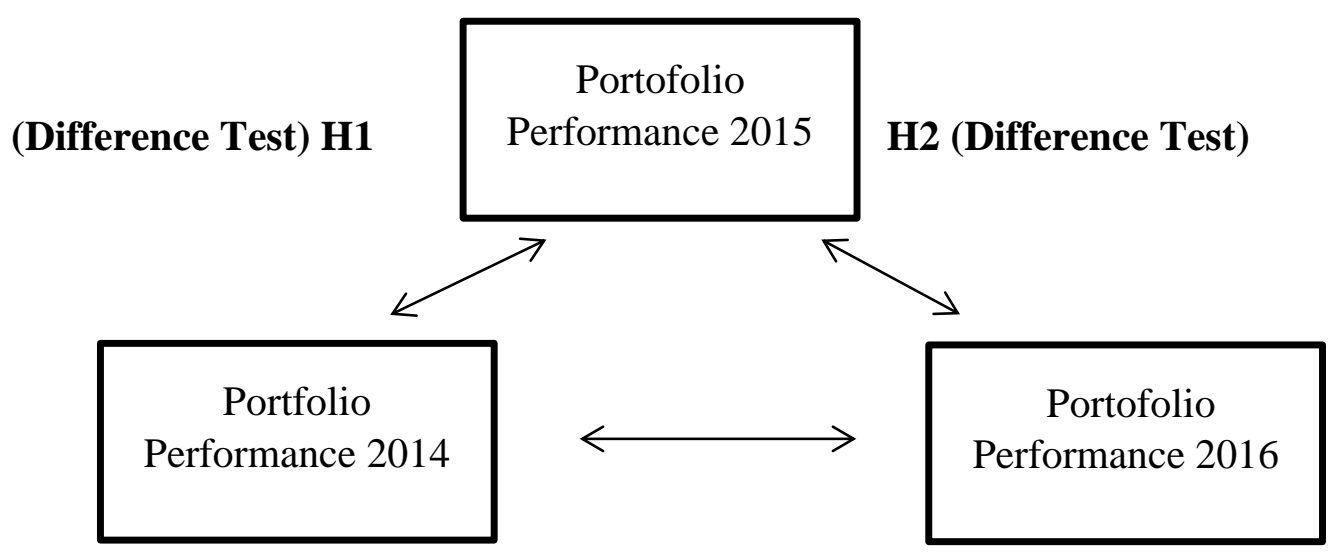

H3 (Difference Test)

Figure 4 Theoretical Framework

\section{Hypothesis}

From the framework model, this research proposed 3 hypotheses $(\mathrm{H} 1, \mathrm{H} 2, \mathrm{H} 3)$ about the syariah stock performance which are:

$\mathrm{H} 0$ :There is no portfolio performance difference between the years of 2014 (before), 2015 (at the time) and 2016 (after).

H1:There is a portfolio performance difference between the years of 2014 (before) with 2015 (at the time).

$\mathrm{H} 2$ :There is a portfolio performance difference between the years of 2015 (at the time), with 2016 (after).

H3:There is a portfolio performance difference between the years of 2014 (before), with 2016 (after).

\section{RESEARCH METHODOLOGY}

This research is a qualitative research which analyzes the optimal portfolio performance comparison which is formed from listed syariah stock in JII. The forming of this portfolio uses the single index method developed bytw William Sharpe. Because that method is more suitable for this research, it is observed that the primary problem in this research is the macroeconomic condition that influenced the index performance. The formed portfolio is also evaluated per semester or every 6 months corresponding with the JII issuance schedule. Such as what is known is that the portfolio strategy is an investment strategy with a short term analysis. The data used is the daily secondary data which is obtained from research documentation results to form a portfolio.

The comparison of portfolio performance is measured by comparing the average daily return per week between portfolios using the risk adjusted performance method developed by Treynor (Treynor Index). So in processing data by comparing the performance index between portfolios per period, 51 samples of data in the form of treynor index values are obtained each day per week in the observation period. As a cause of avoiding performance fluctuations of each stock which is too high, the the portfolio analysis is a short term analysis and the weekly total is stable in one year, where it is not influenced by stock exchange results. In this research the writer is assisted by the computer assistant 
program (software) microsoft excel for forming portfolios and counting the portfolio performance index with the risk adjusted performance method, and the SPSS computer program (software) for implementing the T-test difference test.

\section{Data Type and Source}

In this research, the data used is the secondary data, which is primary data that is continously processed and presented well by the collecting party of the primary data or other parties. Where what becomes the data is the daily closing price of stock per day which goes into the research sample for the research period, the JII closing index per day in the research period, and the BI rate for the research period.

Data for this research was collected and obtained from the Indonesia Stock Exchange Investment Gallery, Faculty of Economics and Business Walisongo Islamic University Semarang, Data collected for this research are:

a. Emmitance list data included in the Jakarta Islamic Index (JII) in the 20132016 period

b. Transaction data of syariah stock prices in the closing per day included in the Jakarta Islamic Index (JII) in the 2013-2016 period included in the sample criteria for counting the stock return;

c. Jakarta Islamic Index (JII) price data in the closing per day in the 2013-2016 period for measuring market return;

d. BI rate data for the 2013-2016 period for counting risk free return;

e. And other related data which supports this research process.

These data are obtained from the sites: http://www.idx.co.id, http://www.ojk.go.id, http://www.bi.go.id, http://www.finance.yahoo.com, http://www.sahamok.com, and other supporting data obtained from internet articles or libraries in the form of bulletins, journals, and other research related and relevant to this research.

\section{Population and Data Sample}

Population is the whole research object, which consist of visible objects, abstracts, events and causes which are the data sources which have certain and same characteristics. Basically the object in this research are the stocks in the JII listing before and after the Indonesian economic weakening of 2015. Because of that the population in this research are the issuers which entered JII in the January 2013 period until the December 2016 period in a row. The determination of that period is based on the Indonesian economy weakening phenomenon in 2015 so it is fine if the syariah stock performance is assessed after the weakening. Besides that, there is a decrease of index performance mid 2015 where before the performance decrease occurred the JII index showed a good performance.

Samples are part of a population where the characteristics will be explored and considered capable of representing the whole population. For avoiding a bias, the purposive sampling method is used, which is a sample selection method with certain criteria. The criteria used in this research are:

1. Stock in the JII category in the December 2013 - May 2014 period for the 1st semester 2014 portfolio period, June - November 2014 period for the 2nd semester 2014 portfolio period, December 2014 - May 2015 period for the 1st semester 2015 portfolio period, June - November 2015 period for the 2nd semester 2015 portfolio period, December 2015 - May 2015 period for the 1 st semester 2016 portfolio period, , June - November 2016 period for the 2 nd semester 2016 portfolio period. 
2. Does not implement corporate action (stock split, stock dividend, and right issue) in the portfolio observation period. The reason is for avoiding biased data analysis results so an increase of the stock price is expected or the stock price decrease is genuine because the transaction volume factor is by investors and is not a cause of corporate action.

\section{Operational and Variable Definition}

Table 2 Portfolio Research Variables

\begin{tabular}{|c|c|c|c|}
\hline \multicolumn{4}{|c|}{$\begin{array}{l}\text { No Variable Remarks } \\
\text { Forming the Single Index Method Optimal Portfolio }\end{array}$} \\
\hline \multicolumn{4}{|c|}{ Forming the Single Index Method Optimal Portfolio } \\
\hline 1 & $\mathrm{R}_{\mathrm{i}}$ & $\begin{array}{l}\text { Counting return stock } \mathrm{i} \text { in the } \mathrm{t} \\
\text { period }\end{array}$ & $\mathrm{R}_{\mathrm{i}}=\frac{P_{t}-P_{t-1}+D_{t}}{P_{t-1}}$ \\
\hline 2 & $\mathrm{E}\left(\mathrm{R}_{\mathrm{i}}\right)$ & $\begin{array}{l}\text { Counting the expected return } \\
\text { stock } \mathrm{i}\end{array}$ & $\mathrm{E}\left(\mathrm{R}_{\mathrm{i}}\right)=\frac{\sum_{t=1}^{n} R_{i t}}{n}$ \\
\hline 3 & $\mathrm{SD}_{\mathrm{i}}$ & $\begin{array}{l}\text { Counting the stock i deviation } \\
\text { standard }\end{array}$ & $\mathrm{SD}_{\mathrm{i}}=\frac{\sum_{t=1}^{n}\left[R_{i t}-E\left(R_{i}\right)\right]^{2}}{n}$ \\
\hline 4 & $\sigma_{i}^{2}$ & Counting the stock i variant & $\sigma_{i}^{2}=\mathrm{SD}^{2}=\left[\frac{\sum_{t=1}^{n}\left[R_{i t}-E\left(R_{i}\right)\right]^{2}}{n}\right]^{2}(5)$ \\
\hline 5 & $\mathrm{R}_{\mathrm{m}}$ & $\begin{array}{l}\text { Counting the JII market return } \\
\text { index period } t\end{array}$ & $\mathrm{R}_{\mathrm{m}}=\frac{J I I_{t}-J I I_{t-1}}{J I I_{t-1}}$ \\
\hline 6 & $\mathrm{E}\left(\mathrm{R}_{\mathrm{m}}\right)$ & $\begin{array}{l}\text { Counting the expected JII } \\
\text { market return index }\end{array}$ & $\mathrm{E}\left(\mathrm{R}_{\mathrm{i}}\right)=\frac{\sum_{t=1}^{n} R_{i t}}{n}$ \\
\hline 7 & $\mathrm{SD}_{\mathrm{m}}$ & $\begin{array}{l}\text { Counting the JII market } \\
\text { deviation standard index }\end{array}$ & $\mathrm{SD}_{\mathrm{m}}=\frac{\sum_{t=1}^{n}\left[R_{m}-E\left(R_{m}\right)\right]^{2}}{n}(8)$ \\
\hline 8 & $\sigma_{m}^{2}$ & $\begin{array}{l}\text { Counting the JII market variant } \\
\text { index }\end{array}$ & $\sigma_{m}^{2}=\left[\frac{\sum_{t=1}^{n}\left[R_{m t}-E\left(R_{m}\right)\right]^{2}}{n}\right]^{2}(9)$ \\
\hline 9 & $\sigma_{\mathrm{im}}$ & $\begin{array}{l}\text { Counting the stock i covariant } \\
\text { with the JII market index }\end{array}$ & $\mathrm{J}_{\mathrm{im}}=\frac{\sum_{t=1}^{n}\left[\left(R_{i t}-E\left(R_{i}\right)\right) \cdot\left(R_{m t}-E\left(R_{m t}\right)\right)\right]}{n}(10$ \\
\hline 10 & $\beta_{\mathrm{i}}$ & Counting the stock i beta value & $\beta_{\mathrm{i}}=\frac{\sigma_{i m}}{\sigma_{m}^{2}}$ \\
\hline 11 & $\alpha_{\mathrm{i}}$ & Counting the stock i alpha value & $\alpha_{\mathrm{i}}=E\left(R_{i}\right)-\beta_{i} \cdot E\left(R_{m}\right)(12)$ \\
\hline 12 & $R_{f}$ & Counting the risk free return & $\mathrm{R}_{\mathrm{f}}=\frac{\sum_{t=1}^{n} B I_{\text {Rate }}}{n}$ \\
\hline 13 & $E R B_{i}$ & $\begin{array}{l}\text { Counting the excess return to } \\
\text { beta }\end{array}$ & $E R B_{i}=\frac{E\left(R_{i}\right)-R B R}{\beta_{i}}$ \\
\hline 14 & $\mathrm{C}_{\mathrm{i}}$ & $\begin{array}{l}\text { Counting the } C \text { value for } \\
\text { determining the cut-off value. } \\
\text { Usually the cut-off value is the } \\
\text { stock with the largest } C \text { value }\end{array}$ & $\mathrm{C}_{\mathrm{i}}=\frac{\sigma_{m \sum_{j=1}^{i} A_{j}}^{2}}{1+\sigma_{m \sum_{j=1}^{2} B_{j}}^{2}}$ \\
\hline 15 & $\mathrm{~W}_{\mathrm{i}}$ & $\begin{array}{l}\text { Counting the } \begin{array}{r}\text { portfolio } \\
\text { composition } \\
\text { (procentage) }\end{array} \\
\text { proportion }\end{array}$ & $\begin{aligned} \mathrm{W}_{\mathrm{i}} & =\frac{Z_{i}}{\sum_{j=1}^{k} Z_{i}} \\
Z_{i} & =\frac{\beta_{i}}{\sigma_{e i}^{2}}\left(E R B_{i}-C^{*}\right)\end{aligned}$ \\
\hline 16 & $\mathrm{R}_{\mathrm{p}}$ & Counting the return portfolio & $\mathrm{R}_{\mathrm{p}}=\frac{R_{p t}-R_{p t-1}}{R_{p t-1}}$ \\
\hline 17 & $E\left(R_{p}\right)$ & $\begin{array}{l}\text { Counting the expected return } \\
\text { portfolio }\end{array}$ & $\mathrm{E}\left(\mathrm{R}_{\mathrm{p}}\right)=\frac{\sum_{t=1}^{n} R_{p t}}{n}(19)$ \\
\hline
\end{tabular}




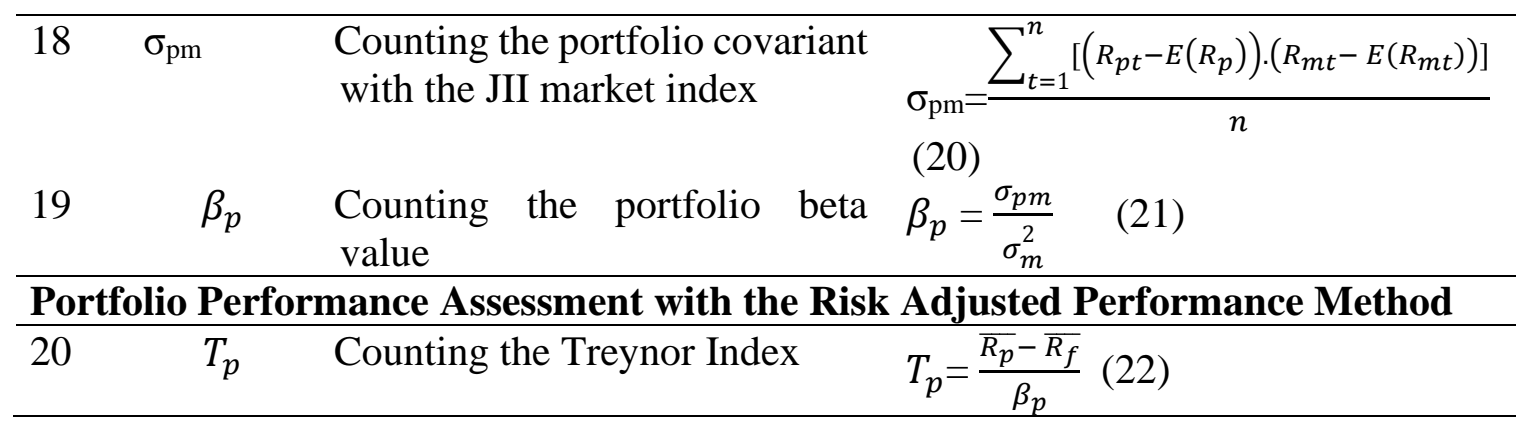

\section{RESULTS AND DISCUSSION Jakarta Islamic Index}

The Jakarta Islamic Index in an index created by PT. Bursa Efek Indonesia (BEI) with PT. Danareksa Investment Management (DIM) based on Islamic syariah in the frame of developing the syariah capital market. This index is meant to be used as a measurement (benchmark) for measuring performance of an investment that enters the JII index, it is implemented with the following order:

1) Selecting stock groups with the primary business of not being against the syariah principle and already recorded for more than 3 months (except being included in the 10 big capitalizations)

2) Selecting stock based on yearly financial reports or the last annual middle which have an obligation to assets as large as $90 \%$ maximum

3) Selecting 60 stocks from the above stock composition based on the average market capitalization order for the last year.

4) Selecting 30 stocks with the composition based on average regular liquidation levels for the last year.

\section{Portfolio 2014}

\section{Semester I}

In the portfolio period of semester I 2014 there are 4 stocks included in the portfolio.

Table 32014 Portfolio Semester I

\begin{tabular}{|c|c|c|c|c|}
\hline No. & $\begin{array}{l}\text { Stock } \\
\text { Code }\end{array}$ & Company Name & Industrial Sector & Percentage \\
\hline 1 & ADRO & Adaro Energy Tbk. & Mining (Coal Mining) & $33.72 \%$ \\
\hline 2 & AALI & Astra Agro Lestari Tbk. & $\begin{array}{l}\text { Agriculture } \\
\text { (Plantation) }\end{array}$ & $41.63 \%$ \\
\hline 3 & LSIP & $\begin{array}{l}\text { PP London Sumatera Indonesia } \\
\text { Tbk. }\end{array}$ & $\begin{array}{l}\text { Agriculture } \\
\text { (Plantation) }\end{array}$ & $3.17 \%$ \\
\hline 4 & UNTR & United Tractors Tbk. & $\begin{array}{l}\text { Trade, Services and } \\
\text { Investment } \\
\text { (Wholesale(Durable } \\
\text { \&Non-Durable } \\
\text { Goods) }\end{array}$ & $21.48 \%$ \\
\hline
\end{tabular}




\begin{tabular}{|c|c|}
\hline UNTR Trade, & ADRO Mining (Coal \\
Services and... & $34 \%$ \\
Mining) & $34 \%$ \\
(Plantation) & AALI Agriculture \\
$3 \%$ & (Plantation); \\
$41,63 \%$
\end{tabular}

\section{Semester II}

Figure 5 Semester 12014 Portfolio Percentage portfolio.

In the portfolio period of semester II there are 5 stocks included in the

Table 42014 Portfolio Semester II

\begin{tabular}{|c|c|c|c|c|}
\hline No. & $\begin{array}{l}\text { Stock } \\
\text { Code }\end{array}$ & Company Name & Industrial Sector & Percentage \\
\hline 1 & SMGR & $\begin{array}{l}\text { Semen Indonesia (Persero) } \\
\text { Tbk. }\end{array}$ & $\begin{array}{l}\text { Basic Industry and Chemicals } \\
\text { (Cement) }\end{array}$ & $13.46 \%$ \\
\hline 2 & INCO & Vale Indonesia Tbk. & $\begin{array}{l}\text { Mining (Metal and Mineral } \\
\text { Mining) }\end{array}$ & $40.72 \%$ \\
\hline 3 & MPPA & Matahari Putra Prima Tbk. & $\begin{array}{l}\text { Trade, Services and Investment } \\
\text { (Retail Trade) }\end{array}$ & $23.94 \%$ \\
\hline 4 & LSIP & $\begin{array}{l}\text { PP London Sumatera Indonesia } \\
\text { Tbk. }\end{array}$ & Agriculture (Plantation) & $10.51 \%$ \\
\hline 5 & AALI & Astra Agro Lestari Tbk. & Agriculture (Plantation) & $11.36 \%$ \\
\hline
\end{tabular}

\begin{tabular}{|c|} 
AALI Agriculture \\
$\begin{array}{c}\text { LSIP Agriculture (Plantation); } \ldots \\
\text { (Plantation);... } \\
\text { MPPA Trade, } \\
\text { Services and... }\end{array}$ \\
INCO Mining \\
(Metal and... \\
\end{tabular}

\section{Portfolio}

Figure 6 Semester 22014 Portfolio Percentage

\section{Semester I}

In the portfolio period of semester I 2015 there are 4 stocks included in the portfolio.

Table 52015 Portfolio Semester I

\begin{tabular}{|c|c|c|c|c|}
\hline No. & $\begin{array}{l}\text { Stock } \\
\text { Code }\end{array}$ & Company Name & Industrial Sector & Percentage \\
\hline 1 & PGAS & $\begin{array}{l}\text { Perusahaan Gas Negara } \\
\text { (Persero) Tbk. }\end{array}$ & $\begin{array}{l}\text { Infrastructure, Utilities and } \\
\text { Transportation (Energy) }\end{array}$ & $12.96 \%$ \\
\hline 2 & PTPP & $\begin{array}{l}\text { Pembangunan Perumahan } \\
\text { (Persero) Tbk. }\end{array}$ & $\begin{array}{l}\text { Property, Real Estate and } \\
\text { Building Construction } \\
\text { (Building Construction) }\end{array}$ & $56.67 \%$ \\
\hline 3 & WIKA & Wijaya Karya Tbk. & $\begin{array}{l}\text { Property, Real Estate and } \\
\text { Building Construction } \\
\text { (Building Construction) }\end{array}$ & $24.62 \%$ \\
\hline 4 & SSMS & $\begin{array}{l}\text { Sawit Sumbermas Sarana } \\
\text { Tbk. }\end{array}$ & Agriculture (Plantation) & $5.75 \%$ \\
\hline
\end{tabular}




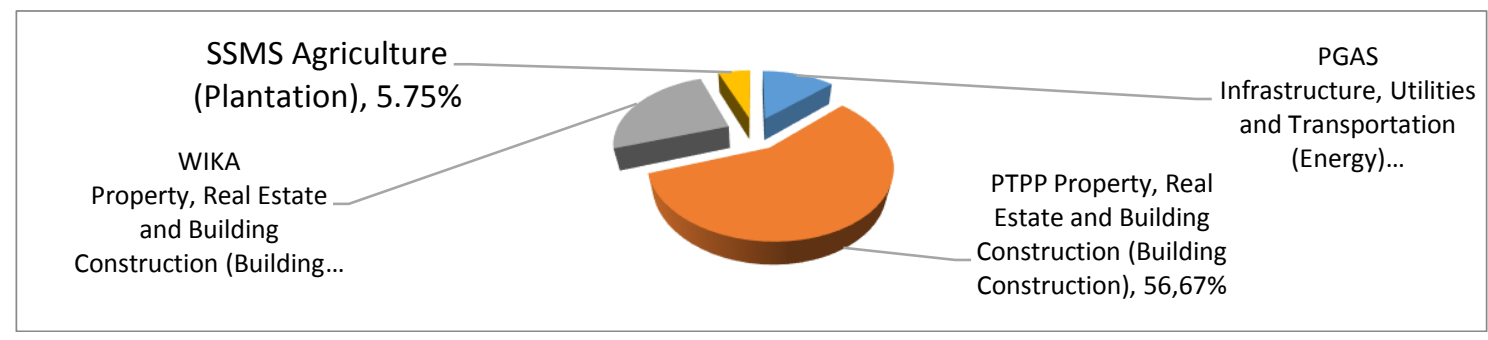

Figure 7 Semester 12015 Portfolio Percentage

\section{Semester II}

In the portfolio period of semester II 2015 there are 11 stocks included in the portfolio.

Table 62015 Portfolio Semester II

\begin{tabular}{|c|c|c|c|c|}
\hline No. & $\begin{array}{l}\text { Stock } \\
\text { Code }\end{array}$ & Company Name & Industrial Sector & Percentage \\
\hline 1 & AKRA & Corporindo & $\begin{array}{l}\text { Trade, Services and Investment } \\
\text { (Wholesale(Durable \&Non-Durable } \\
\text { Goods) }\end{array}$ & $8.72 \%$ \\
\hline 2 & SSMS & $\begin{array}{l}\text { Sawit Sumbermas } \\
\text { Sarana Tbk. }\end{array}$ & Agriculture (Plantation) & $24.56 \%$ \\
\hline 3 & WSKT & $\begin{array}{l}\text { Waskita Karya } \\
\text { (Persero) Tbk. }\end{array}$ & $\begin{array}{l}\text { Property, Real Estate and Building } \\
\text { Construction (Building Construction) }\end{array}$ & $22.04 \%$ \\
\hline 4 & PTPP & $\begin{array}{l}\text { Pembangunan } \\
\text { Perumahan (Persero) } \\
\text { Tbk. }\end{array}$ & $\begin{array}{l}\text { Property, Real Estate and Building } \\
\text { Construction (Building Construction) }\end{array}$ & $9.87 \%$ \\
\hline 5 & SMRA & $\begin{array}{l}\text { Summarecon Agung } \\
\text { Tbk. }\end{array}$ & $\begin{array}{l}\text { Property, Real Estate and Building } \\
\text { Construction (Property and Real } \\
\text { Estate) }\end{array}$ & $7.08 \%$ \\
\hline 6 & MPPA & $\begin{array}{l}\text { Matahari Putra Prima } \\
\text { Tbk. }\end{array}$ & $\begin{array}{l}\text { Trade, Services and Investment } \\
\text { (Retail Trade) }\end{array}$ & $2.27 \%$ \\
\hline 7 & UNTR & United Tractor Tbk. & $\begin{array}{l}\text { Trade, Services and Investment } \\
\text { (Wholesale(Durable \&Non-Durable } \\
\text { Goods) }\end{array}$ & $1.40 \%$ \\
\hline 8 & UNVR & $\begin{array}{l}\text { Unilever Indonesia } \\
\text { Tbk. }\end{array}$ & $\begin{array}{l}\text { Consumer Goods Industry (Cosmetic } \\
\text { Household) }\end{array}$ & $13.14 \%$ \\
\hline 9 & ICBP & Indofood CBP Tbk. & $\begin{array}{l}\text { Consumer Goods Indutry (Food and } \\
\text { Beverages) }\end{array}$ & $7.67 \%$ \\
\hline 10 & LPPF & $\begin{array}{l}\text { Matahari Department } \\
\text { Store Tbk. }\end{array}$ & $\begin{array}{l}\text { Trade, Service and Investment (Retail } \\
\text { Trade) }\end{array}$ & $1.30 \%$ \\
\hline 11 & SILO & $\begin{array}{l}\text { Siloam International } \\
\text { Hospitals Tbk. }\end{array}$ & $\begin{array}{l}\text { Trade, Services and Investment } \\
\text { (Healthcare) }\end{array}$ & $0.31 \%$ \\
\hline
\end{tabular}
Source: Processed Secondary Data 
AN OPTIMAL PORTFOLIO COMPARISON OF SYARIAH STOCKS BEFORE AND

AFTER THE WEAKENING OF THE 2015 INDONESIAN ECONOMY

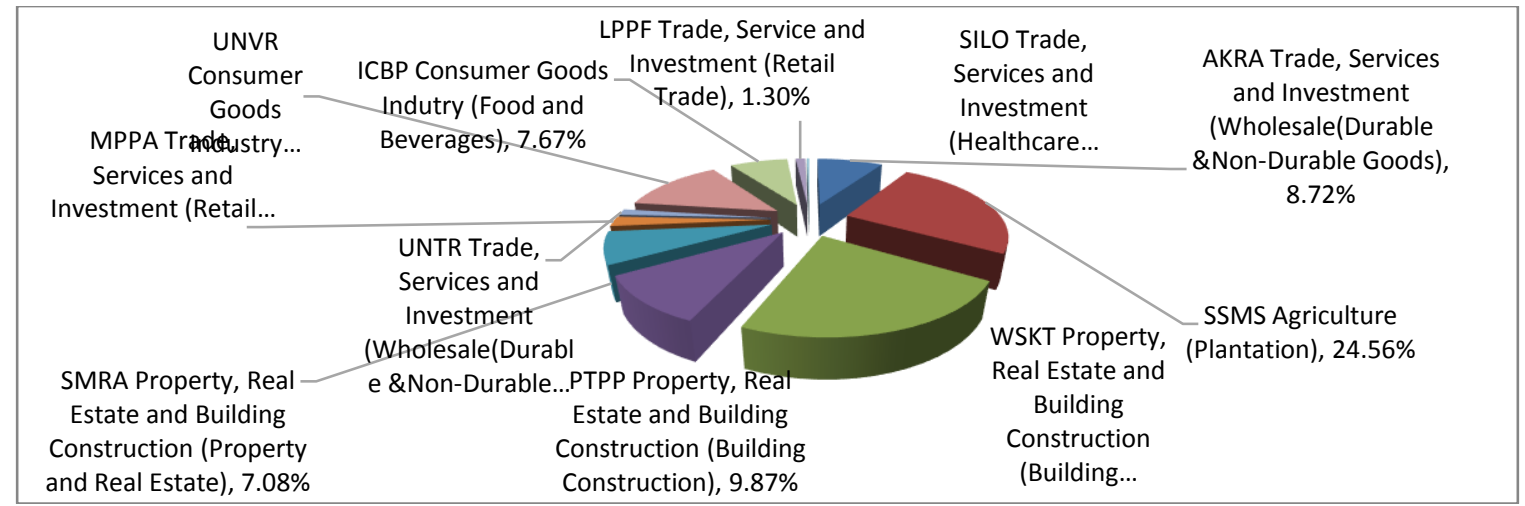

\section{Portfolio}

Figure 8 Semester 22015 Portfolio Percentage

\section{Semester I}

In the portfolio period of semester I 2016 there are 2 stocks included in the portfolio.

Table 52016 Portfolio Semester I

\begin{tabular}{lllll}
\hline No. & Stock Code & \multicolumn{1}{c}{$\begin{array}{c}\text { Company } \\
\text { Name }\end{array}$} & \multicolumn{1}{c}{ Industrial Sector } & Percentage \\
\hline 1 & AKRA & AKR & $\begin{array}{l}\text { Trade, Services and Investment } \\
\text { Corporindo Tbk. }\end{array}$ & $\begin{array}{l}\text { (Wholesale(Durable \&Non-Durable } \\
\text { Goods) } \\
2\end{array}$ \\
PWON & $\begin{array}{l}\text { Pakuwon } \\
\text { Tbk. Jati }\end{array}$ & $\begin{array}{l}\text { Property, Real Estate and Building } \\
\text { Construction (Property and Real } \\
\text { Estate) }\end{array}$ & $19.78 \%$ \\
\hline
\end{tabular}

Source: Processed Secondary Data

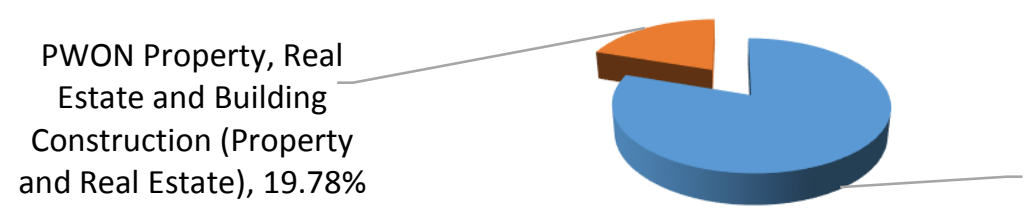

AKRA Trade, Services and Investment

(Wholesale(Durable \&Non-

Durable Goods), $80.22 \%$

\section{Semester II}

Figure 9 Semester 12016 Portfolio Percentage

In the portfolio period of semester II 2016 there are 11 stocks included in the portfolio.

Table 82016 Portfolio Semester II

\begin{tabular}{|c|c|c|c|c|}
\hline No. & $\begin{array}{l}\text { Stock } \\
\text { Code } \\
\end{array}$ & Company Name & Industrial Sector & Percentage \\
\hline 1 & WSKT & $\begin{array}{l}\text { Waskita Karya } \\
\text { (Persero) Tbk. }\end{array}$ & $\begin{array}{l}\text { Property, Real Estate and Building } \\
\text { Construction (Building Construction) }\end{array}$ & $48.56 \%$ \\
\hline 2 & SILO & $\begin{array}{l}\text { Siloam International } \\
\text { Hospitals Tbk. }\end{array}$ & $\begin{array}{l}\text { Trade, Services and Investment } \\
\text { (Healthcare) }\end{array}$ & $2.65 \%$ \\
\hline 3 & SSMS & $\begin{array}{l}\text { Sawit Sumbermas } \\
\text { Sarana Tbk. }\end{array}$ & Agriculture (Plantation) & $4.40 \%$ \\
\hline 4 & INDF & $\begin{array}{l}\text { Indofood Sukses } \\
\text { Makmur Tbk. }\end{array}$ & $\begin{array}{l}\text { Consumer Goods Indutry (Food and } \\
\text { Beverages) }\end{array}$ & $15.24 \%$ \\
\hline 5 & ADRO & Adaro Energy Tbk. & Mining (Coal Mining) & $4.04 \%$ \\
\hline
\end{tabular}




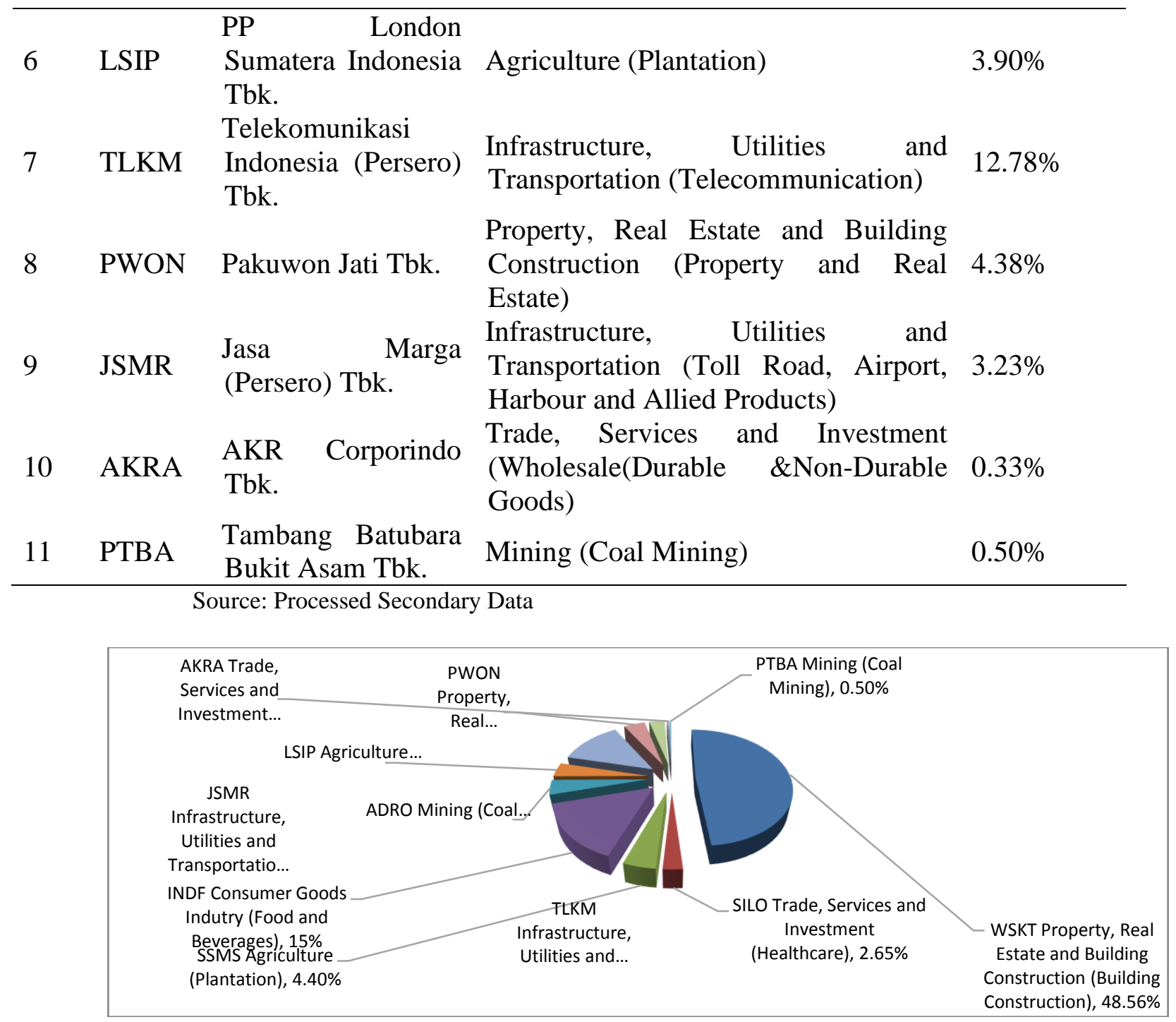

\section{Statistical Data Analysis}

Figure 10 Semester 22016 Portfolio Percentage

Based on the statistical count and analysis to each portfolio, a performance growth graph is obtained which shows the daily performance growth of each week as shown in the following:

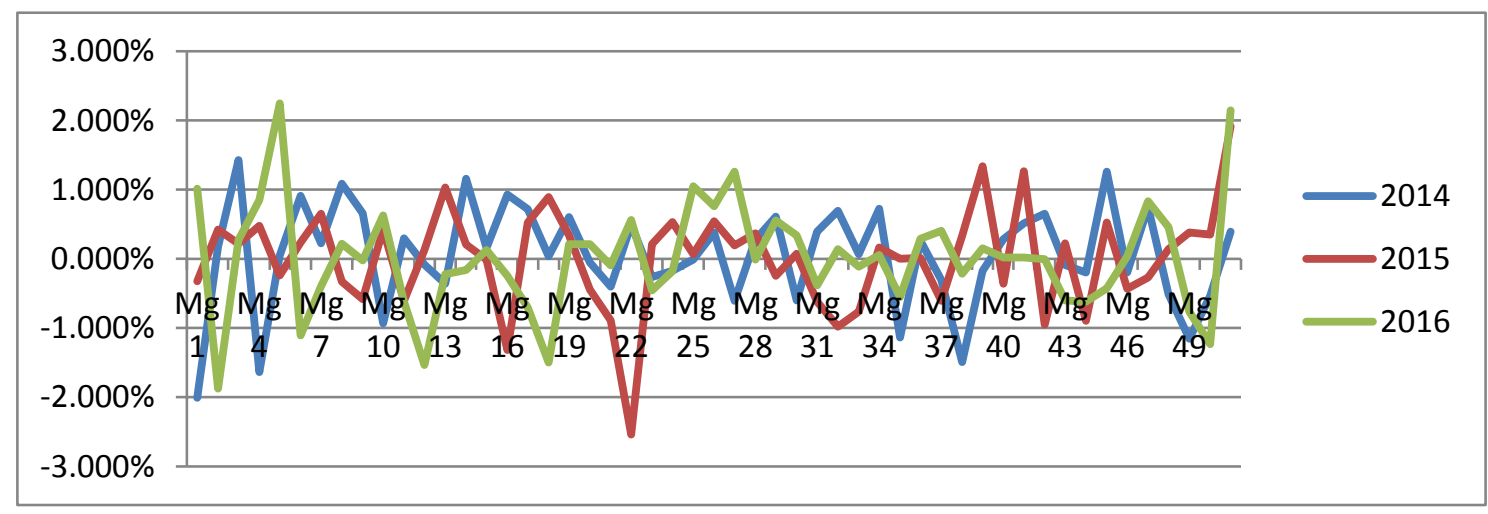

Figure 11 Average Weekly Return Performance between Portfolios

It is seen graphically that the performance of each portfolio provides different results, yet the numbers are not significant. If observed from the global 


\section{AN OPTIMAL PORTFOLIO COMPARISON OF SYARIAH STOCKS BEFORE AND AFTER THE WEAKENING OF THE 2015 INDONESIAN ECONOMY}

economy issue, the weakening occured in mid 2015, where the 2015 portfolio was observed with a deeply negative trend. Yet the numbers do not reach the $3 \%$ average.

Table 9 Return Portofolio Descriptive Data Analysis Results

\begin{tabular}{lccccc}
\hline & $\begin{array}{c}\text { Lowest } \\
\text { Return }\end{array}$ & $\begin{array}{c}\text { Highest } \\
\text { Return }\end{array}$ & $\begin{array}{c}\text { Average } \\
\text { Return }\end{array}$ & $\begin{array}{c}\text { Deviation } \\
\text { Standard }\end{array}$ & $\begin{array}{c}\text { Total } \\
\text { Return }\end{array}$ \\
\hline Portofolio 2014 I & $-2.01 \%$ & $1.43 \%$ & $0.12 \%$ & $1.61 \%$ & $11.40 \%$ \\
JII 2014 I & $-0.76 \%$ & $0.94 \%$ & $0.09 \%$ & $1.17 \%$ & $9.87 \%$ \\
Portofolio 2014 II & $-1.49 \%$ & $1.26 \%$ & $0.01 \%$ & $1.36 \%$ & $-1.80 \%$ \\
JII 2014 II & $-0.84 \%$ & $0.62 \%$ & $0.07 \%$ & $0.90 \%$ & $5.29 \%$ \\
Portofolio 2015 I & $-2.54 \%$ & $1.03 \%$ & $-0.04 \%$ & $1.41 \%$ & $-13.88 \%$ \\
JII 2015 I & $-2.07 \%$ & $1.01 \%$ & $-0.03 \%$ & $1.05 \%$ & $-5.40 \%$ \\
Portofolio 2015 II & $-0.98 \%$ & $1.92 \%$ & $-0.07 \%$ & $1.57 \%$ & $5.07 \%$ \\
JII 2015 II & $-1.45 \%$ & $2.14 \%$ & $-0.09 \%$ & $1.72 \%$ & $-7.86 \%$ \\
Portofolio 2016 I & $-1.87 \%$ & $2.25 \%$ & $-0.04 \%$ & $2.10 \%$ & $-4.17 \%$ \\
JII 2016 I & $-0.89 \%$ & $1.13 \%$ & $0.13 \%$ & $1.05 \%$ & $17.27 \%$ \\
Portofolio 2016 II & $-1.23 \%$ & $2.14 \%$ & $0.07 \%$ & $1.54 \%$ & $5.02 \%$ \\
JII 2016 II & $-1.12 \%$ & $1.74 \%$ & $0.08 \%$ & $1.19 \%$ & $1.06 \%$ \\
\hline
\end{tabular}

Source: Processed Secondary Data

Yet when observed based on statistical counts shown on table 9, it is seen that the portfolio condition has a higher value compared with the JII index. Yet there are some conditions where the portfolio value is lower than the JII index. In semester 12015 and semester 12016 there is a change of the portfolio habit, caused by the presence of the market trend which is caused by investor expectations which change following government expectations. While observed from the risk value, all portfolios have a higher risk value compared with the JII index. This is considered normal, although portfolio forming has a purpose for maximizing returns, with a risk value as minimal as possible, yet for obtaining the maximum return, the risk level will increase.

So in can be concluded that the global and regional economic condition influences the stock price index performance which causes the portfolio performance which is formed by the single index method. Where the portfolio with the single index method is very dependent on value, and the trends and risk values of the stock price. While the average performance value of weekly return portfolios, beta values, variance values, average weekly return index performance and the risk free rate are obtained from the average weekly BI rate which produces values as shown in the following table 10 .

Table 10 Average Return. Beta, Variance Portfolio, Average Index, and Average Risk Free Return

\begin{tabular}{llcccc}
\hline & Avg. Return & $\begin{array}{c}\text { Beta Portofolio } \\
(\boldsymbol{\beta p})\end{array}$ & Variance & JII (Rm) & $\begin{array}{c}\text { BI Rate } \\
(\mathbf{R f})\end{array}$ \\
\hline 2014 I & $0.12 \%$ & 0.596097 & 0.0002586 & $0.09 \%$ & $0.14 \%$ \\
2014 II & $0.01 \%$ & 0.721693 & 0.0001844 & $0.07 \%$ & $0.14 \%$ \\
2015 I & $-0.04 \%$ & 0.577479 & 0.0001977 & $-0.03 \%$ & $0.14 \%$ \\
2015 II & $0.07 \%$ & 0.721047 & 0.0002473 & $-0.09 \%$ & $0.14 \%$ \\
\hline
\end{tabular}




\begin{tabular}{llllll}
\hline 2016 I & $-0.04 \%$ & 0.561066 & 0.0004416 & $0.13 \%$ & $0.13 \%$ \\
2016 II & $0.07 \%$ & 0.922251 & 0.0002357 & $0.02 \%$ & $0.13 \%$ \\
\hline
\end{tabular}

Source: Processed Secondary Databes

Based on the data shown in table 10, each year based portfolio can be measured and compared to the weekly Treynor index performance in each portfolio so it provides a hypothesis test result in the first, second and third hypotheises. The $\mathrm{T}$ test result between the portfolio Treynor index provides the same result, which is the rejection of hypothesis $1(\mathrm{H} 1)$, hypotheisis $2(\mathrm{H} 2)$, and hypotheisis $3(\mathrm{H} 3)$. and the acceptance of hypotheisis 0 (H0) which illustrates that there is no difference between the average weekly performance from every performance measure index.

Table 11 Test Results of the First- Third Hypotheises (2014-2016) T Count T Table Significant Value Significant Level Result

First Hypothesis Test (2014-2015)

\begin{tabular}{|c|c|c|c|}
\hline Treynor Index 0.388 & $2.0086 \quad 0.699$ & 0.05 & H0 accepted \\
\hline \multicolumn{4}{|c|}{ Second Hypothesis Test (2015-2016) } \\
\hline Treynor Index -0.113 & -2.00860 .910 & 0.05 & H0 accepted \\
\hline \multicolumn{4}{|c|}{ Third Hypothesis Test (2014-2016) } \\
\hline Treynor Index 0.259 & $2.0086 \quad 0.797$ & 0.05 & H0 accepted \\
\hline
\end{tabular}

Based on table 11, every t test value and significance value in every performance measure index of each hypothesis test period, there is not one that fulfills the criteria of the hypothesis $0(\mathrm{H} 0)$ rejection and accepts the alternative hypothesises $(\mathrm{H} 1, \mathrm{H} 2, \mathrm{H} 3)$ which explains that performance wise the weekly portfolio does not provide a significant difference. So it can be concluded, that the purpose of forming portfolios for searching for the lowest risk with the maximum return can be said as accomplished, with the proof of the inter-year weekly portfolio before, at the time, and after the Indonesian economic weakening which does not have a significant difference, Which means, the weakening condition of the Indonesian economy in 2015 which is a macroeconomic condition ot can be said as a part of the Beta value (systematic risk) does not influence the average weekly portfolio performance which is formed significantly compared with the years before and after 2015 where the Indonesian macroeconomic condition does not experience growth weakening.

Table 12 Portofolio Return, JII Return and Beta Portofolio

\begin{tabular}{llll}
\hline & \multicolumn{2}{c}{ Portofolio Return $(\mathrm{Rp})$ JII Return $(\mathrm{Rm})$} & Beta Portofolio (Bp) \\
\hline Portofolio 2014 I & $11.40 \%$ & $9.87 \%$ & $59.61 \%$ \\
Portofolio 2014 II & $-1.80 \%$ & $5.29 \%$ & $72.17 \%$ \\
Portofolio 2015 I & $-13.88 \%$ & $-5.40 \%$ & $57.75 \%$ \\
Portofolio 2015 II & $5.07 \%$ & $-7.86 \%$ & $72.10 \%$ \\
Portofolio 2016 I & $-4.17 \%$ & $17.27 \%$ & $56.11 \%$ \\
Portofolio 2016 II & $5.02 \%$ & $1.06 \%$ & $92.23 \%$ \\
\hline
\end{tabular}

Source: Processed Secondary Data 
Yet, when observed and compared with the portfolio return, JII return, and Beta portfolio per semester, it illustrates a different performance with the average weekly performance, there is even something that is not symetrical with the JII market performance index. It is seen from the first semester of 2014 until the first semester of 2015, the semesterly portfolio return is symetrical with the Beta portfolio value. Even though performance wise the average weekly portfolio provided results that there is no significant performance difference. So what becomes the attention is that the analysis of portfolio forming and performance is a short term analysis for adapting to the purpose in forming the portfolio. Based on the result, a rational investor needs to pay attention the implemented investment process specifically in the portfolio forming phase, portfolio revision, portfolio assessment and evaluation and the right timing in making decisions, as the writer explains for maximizing the investment results.

\section{CONCLUSION}

Based on the analysis results implemented for finding the portfolio performance difference of the optimal syariah stock which us arranged by considering the factors before, at the time, and after the weakening of the Indonesian economic growth in 2015, the conclusion is as the following:

1. There is no significant difference in the average weekly Treynor Index in the syariah stock optimal portfolio which is formed from the Jakarta Islamic Index before and at the time of the economic growth weakening in 2015. In other words, there is no difference of average weekly portfolio performance between the 2014 and 2015 portfolios. This result is proven with the insignificant $t$ count value, because the statistical count shows a $t$ count value as large as 0.388 below the $2.0086 \mathrm{t}$ table with a probability value (Sig-t) as large as 0.699 which the value is above the 0.05 significance level.

2. There is no significant difference in the average weekly Treynor Index in the syariah stock optimal portfolio which is formed from the Jakarta Islamic Index before and at the time of the economic growth weakening in 2015. In other words, there is no difference of average weekly portfolio performance between the 2014 and 2016 portfolios. This result is proven with the insignificant $t$ count value, because the statistical count shows a $t$ count value as large as -0.113 below the $2.0086 \mathrm{t}$ table with a probability value (Sig-t) as large as 0.910 which the value is above the 0.05 significance level.

3. There is no significant difference in the average weekly Treynor Index in the syariah stock optimal portfolio which is formed from the Jakarta Islamic Index before and at the time of the economic growth weakening in 2015. In other words, there is no difference of average weekly portfolio performance between the 2014 and 2016 portfolios. This result is proven with the insignificant $t$ count value, because the statistical count shows a $t$ count value as large as 0.259 below the $2.0086 \mathrm{t}$ table with a probability value (Sig-t) as large as 0.797 which the value is above the 0.05 significance level.

4. The conclusion from the three tested hypotheises provides an illustratio of the portfolio forming strategy in investment in the years 2014, 2015 and 2016, with the presence of an economic growth weakening in the year 2015 as a systematic risk variable which can be minimalized. This shows the portfolio strategy to be in the reach of the goal of portfolio forming. 


\section{References}

Ahmad, K. (2004). Dasar-Dasar Manajemen Investasi dan Portofolio. Jakarta: PT. Rineka Cipta. p. 2.

Brigham, E. F., \& Houston, J. (2009). Fundamentals of Finance Management. Terj. Ali Akbar Yulianto. Jakarta: Salemba Empat. p. 216.

Hartono, J. (2014). Teori dan Praktik Portofolio dengan Excel. Jakarta: Salemba Empat. p. 7-8.

Hartono, J. (2007). Teori Portofolio dan Analisis Investasi. Yogyakarta: BPFE Yogyakarta. p. 207.

PT Bursa Efek Indonesia. Sekolah Pasar Modal Syariah Tahun 2011. p.3.

Samsul, M. (2006). Pasar Modal dan Manajemen Portofolio. Jakarta: Erlangga. p. 35.

Subekhi, I. (2011). Analisis Perbandingan Kinerja Portofolio Saham Syariah Sebelum dan Sesudah Listing di Jakarta Islamic Index (Studi pada sahamsaham di JII periode 5 Desember 2008 - 8 Juni 2011. [Theisis]. Semarang: Walisongo Public Islamic University. p. 111-114.

Sudandarumini. (2002). Metedologi Penelitian Petunjuk Praktis Untuk Penelitian Pemula. Yogakarta: Gajah Mada University Press. p. 47.

Sulistyorini, A. (2009). Analisis Kinerja Portofolio Saham dengan Metode Sharpe, Treynor, dan Jensen (Saham LQ45 di Bursa Efek Indonesia Tahun 2003-2007). [Tesis]. Semarang: Diponegoro University. p. 62-63.

Tandelilin, E. (2001). Analisis Investasi dan Manajemen Portofolio. Yogyakarta: BPFE Yogyakarta. p. 17.

Tandelilin, E. (2001). Analisis Investasi dan Manajemen Portofolio. Yogyakarta: BPFE Yogyakarta. p. 327

Tuerah, C. (2013). Perbandingan Kinerja Saham LQ45 Tahun 2012 Menggunakan Metode Jensen, Sharpe dan Treynor. EMBA Journal. 1 (4). p. 1447

Umar, H. (2000). Research Methods in Finance and Banking. Jakarta: PT Gramedia Pustaka Utama. Print. II. p. 82

Utami, R. dan Nugraha, M. (2011). Analisis Kinerja Saham Syariah dan Pengaruhnya Terhadap Respon Pasar pada Perusahaan yang Tercatat di JII. Jurnal Reviu Akuntansi dan Keuangan. 1 (2). p. 169-170. 